\title{
Gene expression in the mammary gland
}

\author{
S. Harris*, M. McClenaghan, J. P. Simons, S. Ali† and A. J. Clark \\ AFRC Institute of Animal Physiology and Genetics Research, Edinburgh Research Station, \\ Roslin, Midlothian EH25 9PS, UK
}

Keyw'ords: Mammary gland; $\beta$-lactoglobulin; transgenic; gene expression

\section{Introduction}

The mammary gland is the specialized secretory organ that provides essential nourishment to mammalian young in the form of milk. Milk is primarily composed of water, fats, lactose and proteins; the major protein components are the various caseins and the whey proteins $\alpha$-lactalbumin, $\beta$-lactoglobulin (ruminants) and whey acidic protein (rodents).

Mammary development and milk protein gene expression are regulated by a number of peptide and steroid hormones, as well as cell-cell and cell-substratum interactions within the gland (Topper \& Freeman, 1980; Levine \& Stockdale, 1985; Li et al., 1987). During gestation the secretory capacity of the mammary gland increases due to cellular proliferation and differentiation; concomitantly milk protein gene expression is initiated in preparation for sustained milk production after parturition. In late lactation milk production declines due to decreased demand, and at weaning rapid mammary gland involution occurs to a state that approximates that of the mature virgin gland. Our present understanding of the relative contribution that hormones and morphological factors have on mammary gland development and milk protein gene expression results from investigations in the whole animal and in vitro, including mammary gland explants (Topper et al., 1975) and mammary epithelial cell culture systems (Rosen et al., 1986).

Man has traditionally exploited ruminant milk and its products as a source of dietary protein and in the food technology industry (see Fox, 1982). It has recently been proposed that manipulation of milk composition is a candidate for genetic manipulation in domestic dairy animals (Wagner \& Murray, 1985; Lathe et al., 1986; Clark et al., 1987; Jimenez-Flores \& Richardson, 1988). Several groups have successfully demonstrated the feasibility of targeting gene expression to the mammary gland of mice (Stewart et al., 1984; Ross \& Solter, 1985; Leder et al., 1986; Andres et al., 1987; Choi et al., 1987; Gordon et al., 1987; Simons et al., 1987; Lee et al., 1988; Muller et al., 1988; Schonenberger et al., 1988; Tsukamoto et al., 1988; Bouchard et al., 1989; Lee et al., 1989; Tremblay et al., 1989). In Edinburgh, transgenic sheep carrying hybrid gene constructs that express a human plasma protein in their milk have been generated (Simons et al., 1988; Clark et al., 1989). At present the levels of expression of the transgenic protein in the milk are low and this illustrates the need for a greater understanding of the structure and regulation of the milk protein genes used to target expression to the mammary gland (Clark et al., 1989).

A number of genomic clones encoding milk proteins have been isolated and their organizations described (Yu-Lee \& Rosen, 1983; Campbell et al., 1984; Qasba \& Safaya, 1984; Jones et al., 1985; David-Inouye et al., 1986; Yu-Lee et al., 1986; Hall et al., 1987; Kawara et al., 1987; Vilotte et al., 1987; Alexander et al., 1988; Ali \& Clark, 1988; Devinoy et al., 1988; Gorodetsky et al., 1988; Laird et al., 1988). The identification of DNA sequence elements that contribute to regulated milk protein

\footnotetext{
*Present address: Glaxo Group Research Ltd, Greenford Road, Greenford, Middlesex UB6 0HE, UK.

†Present address: INSERM U184 CNRS LGME, Institute de Chimie Biologique, Faculté de Médecine, 11 Rue Humann, 67085 Strasbourg Cedex, France.
} 
gene expression has been impeded by the absence of a suitable system in which to evaluate expression of manipulation DNA sequences. Intra- and inter-species DNA sequence comparisons have suggested common regulatory elements in the promoter region of a number of different caseins and whey proteins (Yu-Lee \& Rosen, 1983; Jones et al., 1985; Yu-Lee et al., 1986; Bisbee \& Rosen, 1986; Hall et al., 1987; Devinoy et al., 1988; Laird et al., 1988). Furthermore, an in-vitro DNA-protein interaction has been proposed between part of this DNA sequence motif and nuclear protein(s) isolated from various tissues, including the mammary gland (Lubon \& Hennighausen, $1987,1988)$. A cell system has been described that allows characterization of the rat $\beta$-casein promoter covering this region (Ball et al., 1988; Doppler et al., 1989); the applicability of this cell system to other milk protein genes has yet to be demonstrated. While the significance in vivo of these observations remains unclear, the advent of methods for generating transgenic animals containing manipulated DNA sequences allows the investigation of milk protein gene expression in the whole animal, under the influence of all contributory factors.

\section{Generation of transgenic animals}

There are currently three methods for incorporating exogenous DNA into the genome to produce transgenic animals. These are (1) retroviral vectors, (2) embryonic stem cells and (3) pronuclear microinjection (Palmiter \& Brinster, 1986; Scangos \& Bieberich, 1987; Simons \& Land, 1987). At present most transgenic animals are produced by pronuclear microinjection of fertilized eggs (Fig. 1). Fertilized eggs are obtained from superovulated donor animals and tens to hundreds of DNA molecules are injected through a fine injection pipette into one of the pronuclei. Surviving eggs are implanted into foster mothers and proceed to term.

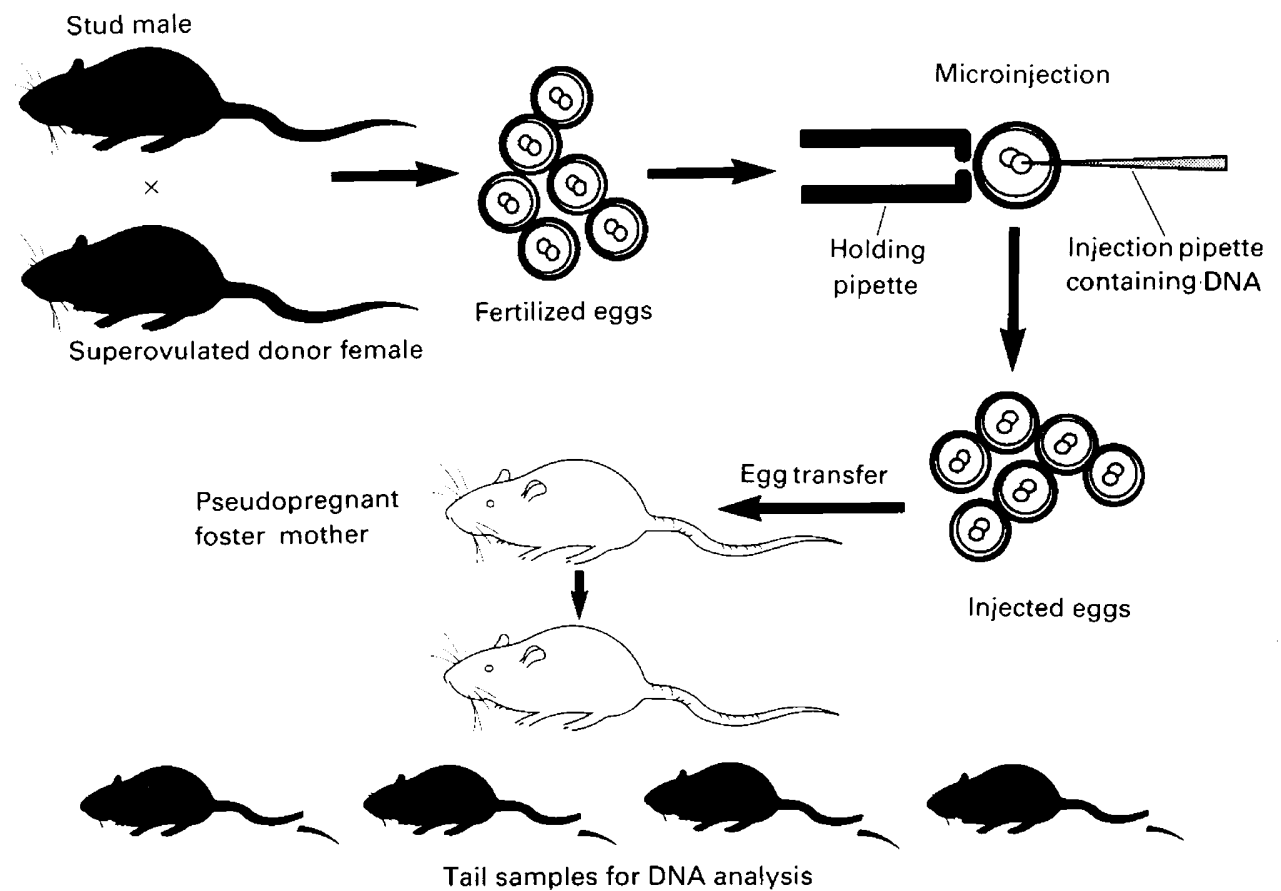

Fig. 1. Production of transgenic mice by pronuclear injection (see text for details). 
Transgenic offspring are identified by molecular analysis of their DNA for the presence of the injected DNA molecule(s). The integrated DNA is frequently present in every cell at a single chromosomal location, usually as multiple copies in a tandem array. In mice up to $5 \%$ of injected eggs may develop to be transgenic. In domestic animals, such as sheep or pigs, the average success rate is approximately $1 \%$. This may reflect differences in both reproductive physiology and the technical demands of microinjection into more fragile and almost opaque eggs (Simons et al., 1988).

\section{Ovine $\beta$-lactoglobulin}

We have chosen to investigate expression of the gene encoding ovine $\beta$-lactoglobulin (BLG). $\beta$-Lactoglobulin is a whey protein of $M_{\mathrm{r}} 18000$ present in ruminant milk at a concentration of about $3 \mathrm{~g} / \mathrm{l}$. It is also found in the milk of horses, pigs, dogs and dolphins, but not in that of rodents and humans (Jenness, 1982; Pervaiz \& Brew, 1985). While the protein has no recognized function it is related to a diverse family of other secretory proteins, many of which bind small lipophilic molecules (for references, see Ali \& Clark, 1988; Ali, 1989). The genomic ovine BLG gene has been isolated and more than $7 \mathrm{~kb}$ of the DNA sequence encompassing the structural gene have been determined (Ali \& Clark, 1988; Harris et al., 1988). The DNA sequence suggests that a functional gene has been isolated, not a pseudogene, and that the pre-protein of 180 amino acids is encoded by 7 exons covering $4.9 \mathrm{~kb}$ of genomic DNA (Fig. 2). However, it remained to be demonstrated whether the isolated BLG gene contains the necessary cis regulatory sequences for efficient, regulated expression in the mammary gland.

(a)

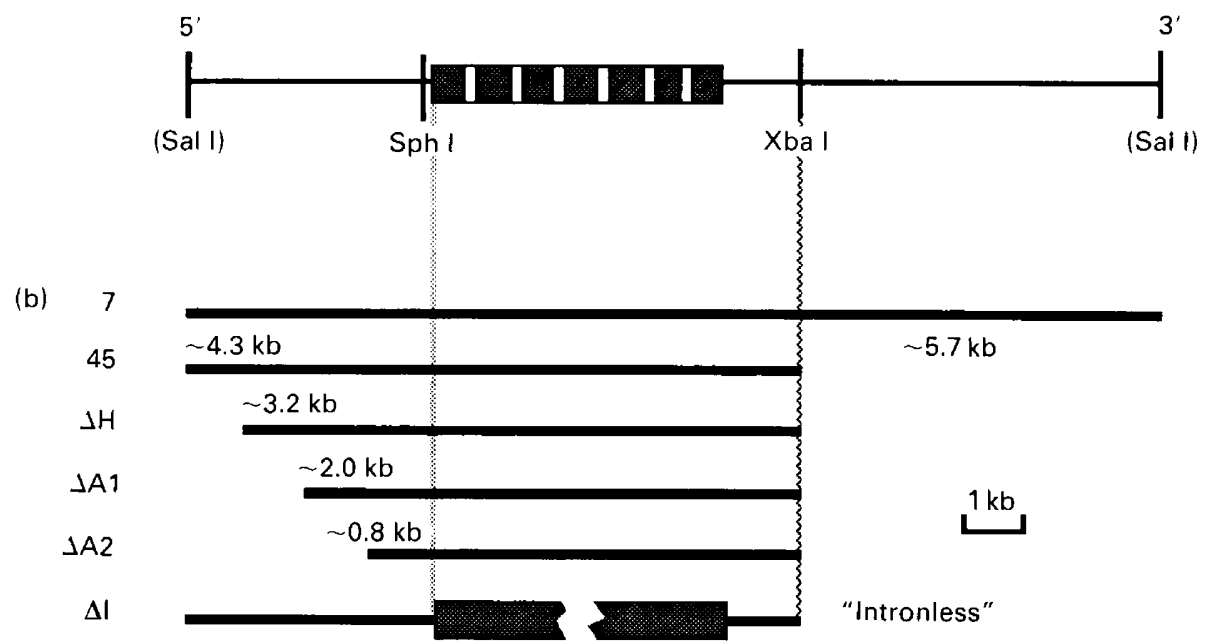

Fig. 2. Organization of the ovine $\beta$-lactoglobulin clone SS1. (a) Bold line represents $5^{\prime}$ and $3^{\prime}$ flanking DNA while exon and intron sequences (not to scale) are represented by stippled and open boxes, respectively. (b) The extent of various regions of DNA used to generate transgenic mice by pronuclear injection: 7 and 45 correspond to lines of mice generated with the particular region illustrated (for results see Figs 3, 4 and 5) while $\Delta \mathrm{H}, \Delta \mathrm{Al}, \Delta \mathrm{A} 2$ and $\Delta \mathrm{I}$ are construct identifiers.

In the absence of a suitable in-vitro cell system in which to evaluate BLG expression we have investigated the ability of various BLG DNA constructs to direct the expression of BLG protein in milk of transgenic mice (Simons et al., 1987; S. Harris, P. Simons \& M. McClenaghan, unpublished 
results). In parallel, we are also investigating the potential of transgenic sheep containing BLGfusion genes as a source of authentic human protein in milk (Simons et al., 1988; Clark et al., 1989; A. Archibald, unpublished results). A mouse system would therefore be a rapid means of evaluating BLG-fusion constructs for their potential to direct the expression of a foreign protein in the milk of a domestic ruminant.

\section{The mouse model system}

To evaluate sheep BLG expression in mice, genomic DNA sequences must be correctly transcribed, mRNA translated, and the protein correctly processed and secreted into the milk, despite the absence of the BLG gene in mice. The ability of transgenes to direct the production of BLG protein or BLG-fusion gene products in a tissue-specific, regulated manner requires the presence of cisacting DNA sequences that control BLG expression. In the absence of any information regarding the position of such sequences within the ovine clone SS1, the largest genomic DNA fragment from this clone was initially used to produce transgenic mice (Simons et al., 1987). Additional lines of mice have been generated containing derivative BLG constructs to define more precisely those cisacting DNA sequence elements important for tissue-specific, regulated expression (Simons et al., 1987; Fig. 2).

The ability of various BLG constructs to direct the expression of BLG in mouse milk can generally be assessed by SDS polyacrylamide gel electrophoresis and Coomassie Blue staining of milk whey proteins as shown in Fig. 3(a). An additional protein of $M_{\mathrm{r}} 18000$ is present in milk from lactating transgenic mice, all other protein bands being present in milk from transgenic and control animals. This additional protein co-migrates with purified BLG, and western blotting of milk whey proteins confirms the identity of this protein as BLG (Fig. 3 b). In abundantly expressing lines the level of BLG protein in mouse milk can be up to 5 times that present in sheep milk (e.g. line 7). This change in milk composition is not accompanied by any apparent deleterious side effects, either to the hemizygous transgenic females or their sucking offspring. Copy number-independent variations in BLG protein content are evident in different lines of mice containing the same BLG construct (e.g. lines $23 \& 41$ ), probably reflecting the influence of the site of integration on transgene expression in different lines (Palmiter \& Brinster, 1986).

All the $5^{\prime}$ and $3^{\prime}$ flanking deletion constructs express similarly variable levels of BLG protein in the milk of transgenic mice (Fig. 2; S. Harris \& M. McClenaghan, unpublished results). In contrast, the milk from three $\mathrm{G} 0$ females containing the intronless BLG construct ( $\Delta \mathrm{I}$, Fig. 2) express a consistently low level of protein, detectable only by western blotting (S. Harris \& $\mathbf{M}$. McClenaghan unpublished results). This suggests a possible requirement for intron sequences for efficient BLG expression in transgenic mice. However, the ability of the BLG promoter region to direct significant levels of a foreign protein from a genomic DNA sequence containing introns (A. Archibald, unpublished results) suggests this may be a non-specific requirement, rather than a requirement for specific BLG intron sequences. It is also possible, although unlikely, that all 3 animals were either somatic mosaics or low level expressors, due to the site of integration. The dependence of gene expression on the presence of intron sequences has been noted by others (Brinster et al., 1988). Further lines of mice would need to be analysed to clarify the mechanism(s) by which, intron sequences influence BLG expression in transgenic systems.

The tissue distribution of BLG expression has been examined in total RNA isolated from a variety of tissues and analysed after Northern blotting using BLG-specific cDNA probes (Simons et al., 1987; Fig. 4). Mice expressing BLG protein in their milk contain a transcript present in RNA isolated from the lactating mammary gland that co-migrates with the equivalent sheep transcript of about 800 nucleotides (Gaye et al., 1986). All BLG deletion constructs retain this strict tissuespecific expression pattern in transgenic mice, including the intronless gene ( $\mathrm{S}$. Harris, unpublished results). Furthermore, in all lines examined the RNA transcript initiates at the previously identified 
(a)

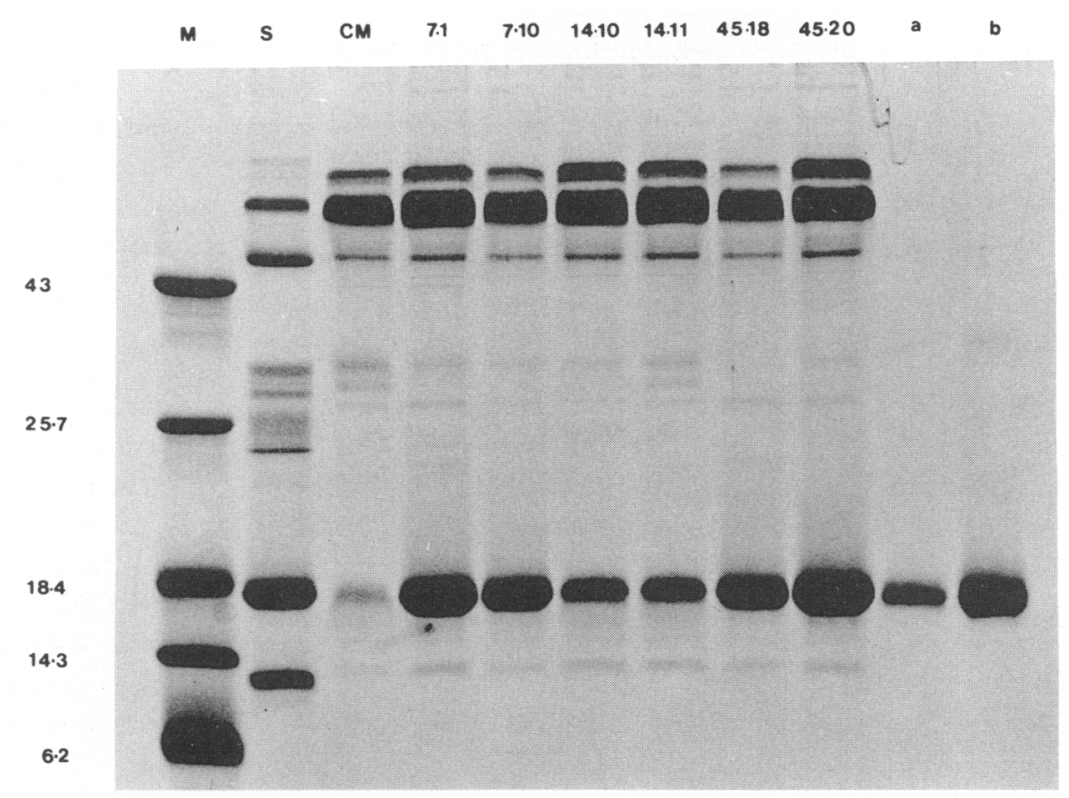

(b)
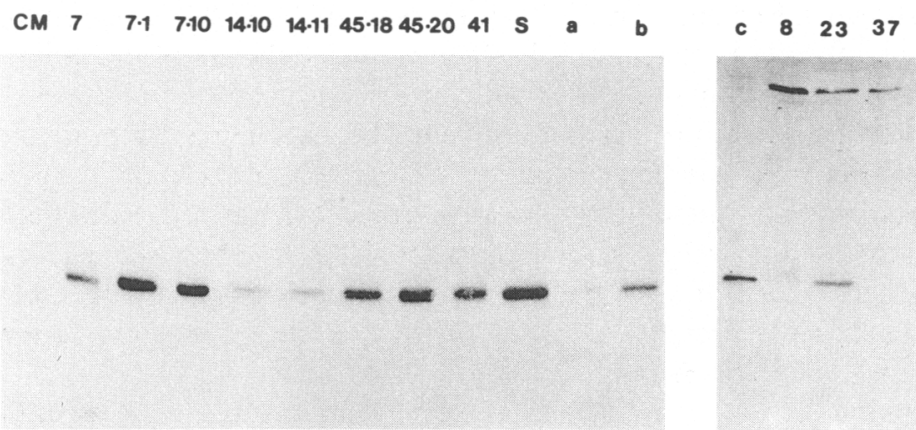

d 23.523 .9

Fig. 3. Analysis of whey proteins in the milk of mice transgenic for sheep $\beta$-lactogobulin (BLG) (a) Milk samples were diluted $1 / 5$ in distilled water and defatted by centrifugation. To prepare whey, the caseins were precipitated by the addition of $1 \mathrm{M}-\mathrm{HCl}$ to $\mathrm{pH} 4 \cdot 5$. Whey proteins $(150 \mu \mathrm{l})$ were precipitated in $5 \% \mathrm{TCA}$, washed in acetone, solubilized in $100 \mu \mathrm{l}$ loading buffer and electrophoresed on $15 \%$ polyacrylamide gels. Solubilized whey protein $(2.0 \mu 1)$ from each transgenic mouse (as numbered) and one control mouse (CM) are shown electrophoresed alongside $10.0 \mu \mathrm{l}$ sheep whey protein (S), markers (M) and $2.5 \mu \mathrm{g}(\mathrm{a})$ and $10 \mu \mathrm{g}$ (b) of purified sheep BLG. (b) Western blot of whey proteins probed for sheep BLG. Samples from transgenic animals are in numbered lanes, from control mouse in lane CM and from sheep in lane $S$. Solubilized whey $(1 \mu \mathrm{l}$ is equivalent to $0 \cdot 3 \mu \mathrm{l}$ milk) was loaded as follows: $0 \cdot 1 \mu \mathrm{l}$ for all transgenic samples except $7(0 \cdot 5 \mu \mathrm{l}) ; 23.5$ and $23 \cdot 9(3 \mu \mathrm{l}) ; 8,23$ and $37(5 \mu \mathrm{l}) ; 1 \mu \mathrm{l}$ for $\mathrm{CM}$ and $\mathrm{S}, 3 \mu \mathrm{l}$. Standards are shown in lanes $a, b, c$ and $d$ and correspond to $100,500,2$ and $100 \mathrm{ng}$ purified BLG, respectively: note that $a$ and $b$ apply to the first 10 lanes, $c$ to lanes 8,23 and 37 and $d$ to lanes 23.5 and 23.9. The high $M_{\mathrm{r}}$ band in tracks 8,23 and 37 is due to non-specific binding of the antiserum. For further details see Simons et al. (1987). Part of figure reproduced by permission from Simons et al. (1987).

cap site (Ali, 1989; P. Brown \& S. Harris, unpublished results). Moreover, when examined by immunohistochemical analysis, BLG protein expression is specific to the secretory epithelial cells within the mammary gland (S. Harris \& M. McClenaghan, unpublished results). 

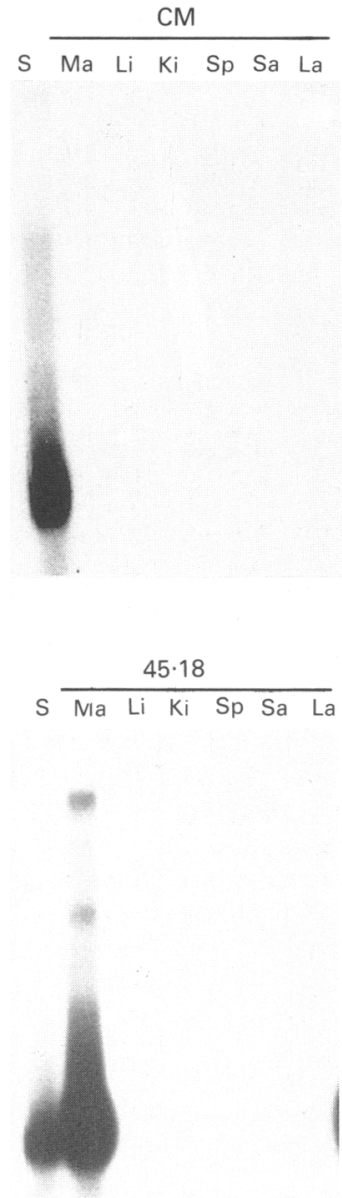
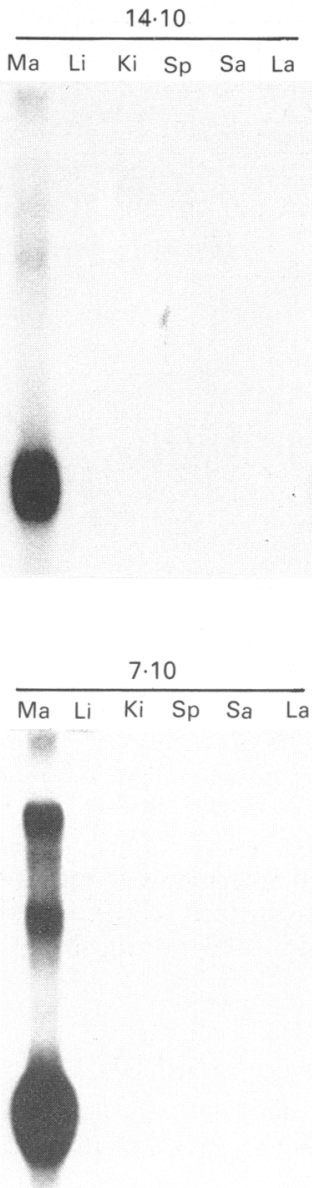

Fig. 4. Tissue-specific expression of the sheep BLG gene in the mammary gland of transgenic mice. Northern blot analysis of $5 \mu \mathrm{g}$ total RNA from 11-day lactating transgenic mice (numbered) and a control animal C57BL/6 (CM). The tissues analysed are mammary gland $(\mathrm{Ma})$, liver (Li), kidney (Ki), spleen (Sp), salivary gland (Sa), and lachrymal gland (La). Lane $\mathbf{S}=$ RNA from the mammary gland of a lactating ewe. Duplicate transgenic mice give essentially identical results. For further experimental details see Simons et al. (1987). Reprinted by permission from Simons et al. (1987).

Occasionally a low abundance RNA transcript could be seen in other tissues after a long exposure, particularly in the salivary gland. This is most likely to be due to contamination of this tissue during dissection by thoracic mammary gland tissue because (1) other endogenous murine mammary specific transcripts that are known not to be expressed in the salivary gland are also present (e.g. $\beta$-casein), and (2) the quantity of salivary gland BLG transcript present in a given RNA sample fluctuates for a given transgenic line.

We have demonstrated abundant tissue-specific expression of the ovine BLG gene in transgenic mice. However, for the mouse model to be a useful representation of BLG gene expression in sheep it is also important that gene expression is temporally and developmentally regulated rather than constitutive. To examine this aspect of regulation in transgenic mice total RNA was isolated from virgin mice and other animals killed at specific times during gestation, lactation and weaning. Using RNA dot-blot analysis the level of BLG-specific RNA was determined for each time point (Fig. 5; S. Harris, unpublished). 

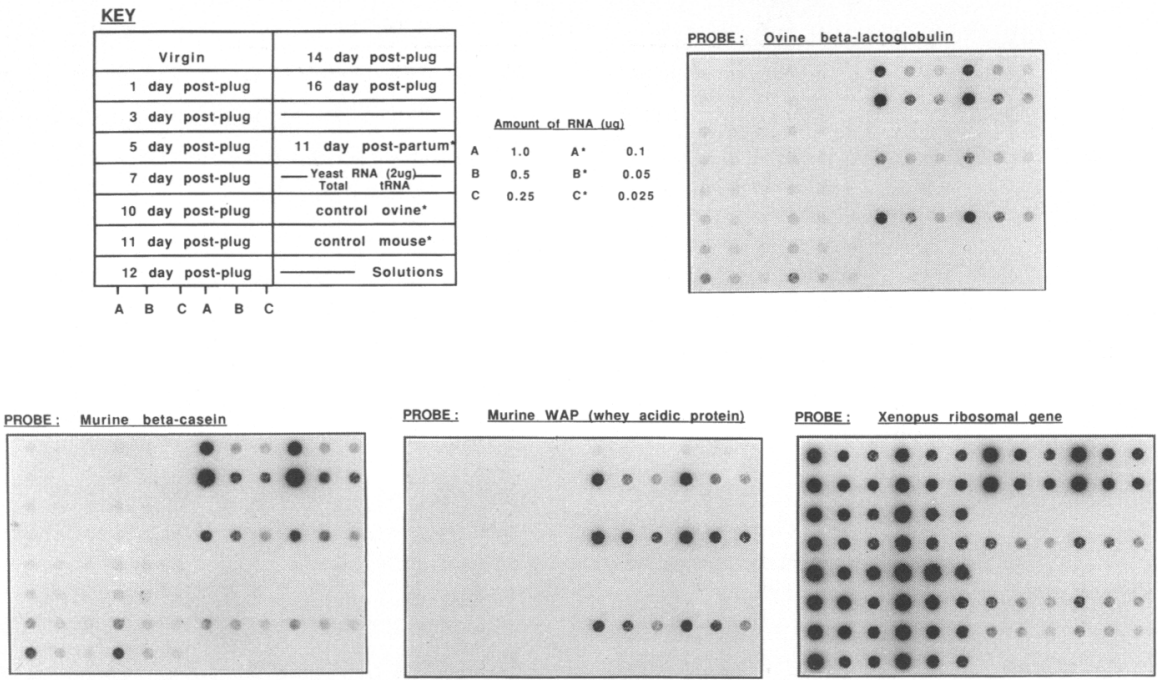

Fig. 5. Expression of the ovine $\beta$-lactoglobulin gene during gestation in transgenic mice. Total RNA values isolated from mammary gland tissue at different days during gestation are shown after hybridization to ${ }^{32} \mathrm{P}$-labelled DNA probes. RNA samples were transferred to filters through a manifold. Control mouse (C57BL/6), control sheep and 11-day post-parturient RNA samples were diluted 10-fold compared to gestation samples (line 7, see Fig. 1). The ovine $\beta$-lactoglobulin probe was derived from $\mathrm{p} 931$ (Gaye et al., 1986); the murine $\beta$-casein probe was from pCas51 (Mehta et al., 1981); the murine WAP probe from pmWAP1 (Hennighausen \& Sippel, 1982) and the Xenopus ribosomal rDNA probe was from pMB9 (Sollner-Webb \& Reeder, 1979).

When the expression profile for BLG is compared to that of RNA encoding other endogenous murine milk proteins, BLG is expressed with a developmental profile similar to that of endogenous murine $\beta$-casein, but different from that of the murine whey acidic protein. This BLG expression profile in mice resembles that established for BLG in sheep when equivalent time points are examined (Ali, 1989). Similar results are also obtained for deletion constructs over a limited time course ( $\mathrm{S}$. Harris, unpublished results). These observations, that the BLG transgene is temporally and developmentally regulated in transgenic mice, suggest that all the essential cis-acting DNA sequences required for regulated expression of the ovine BLG gene are represented within the deletion construct $\triangle \mathrm{A} 2$ (Fig. 1).

\section{Summary and conclusions}

We have demonstrated that the ovine genomic clone SS1 can be used to generate transgenic mice that produce significant quantities of BLG protein in milk. The smallest BLG construct so far examined that retains the ability to direct BLG to mouse milk encompasses approximately $7 \cdot 3 \mathrm{~kb}$ of genomic DNA, of which about $0.8 \mathrm{~kb}$ is derived from the promoter region. Gene expression is tissue-specific and regulated in a temporal and developmental fashion that is similar to that reported for sheep. We conclude, therefore, that the cis-acting sequences determining mammary expression of the ovine BLG gene are correctly interpreted in mice, despite the absence of an equivalent gene in this species, and that conclusions drawn from future work on BLG expression in the mammary gland of transgenic mice will be broadly applicable in sheep and other ruminant species.

Work is currently in progress to define other sequences within the promoter of BLG that are required for regulated expression in transgenic mice. These and other studies into the DNA-protein 
interactions within the promoter which are required for efficient tissue-specific, regulated expression should lead to a greater understanding of milk protein gene expression in the mammary gland. Furthermore, in the current absence of a suitable in-vitro system, the mouse will be most useful for evaluating the expression of further constructs designed to express foreign proteins in milk of domestic ruminants.

S.H. thanks Mrs S. Couperwhite for technical assistance; those involved in generating and maintaining mice, in particular Miss R. Wallace; and Mrs A. Griffiths, Glaxo Group Research Ltd, for typing the manuscript. This work was supported by the AFRC.

\section{References}

Alexander, L.J., Stewart, A.F., Mackinley, A.G., Kapelinskaya, T.V., Tkach, T.M. \& Gorodetsky, S.I. (1988) Isolation and characterisation of the bovine kappa-casein gene. Eur. J. Biochem. 178, 395-401.

Ali, S. (1989) Structure and expression of the gene encoding ovine $\beta$-lactoglobulin. Ph.D. thesis, University of Edinburgh, Scotland.

Ali, S. \& Clark, A.J. (1988) Characterisation of the gene encoding ovine $\beta$-lactoglobulin: similarity to the genes for retinol binding protein and other secretory proteins. J. molec. Biol. 199, 415-426.

Andres, A.-C., Schonenberger, C.-A., Groner, B., Hennighausen, L., LeMeur, M. \& Gerlinger, P. (1987) Ha-ras oncogene expression directed by a milk protein gene promoter: tissue specificity, hormonal regulation and tumour induction in transgenic mice. Proc. natn. Acad. Sci. USA 84, 1299-1303.

Ball, R.K., Friis, R.R., Schonenberger, C.A., Doppler, W. \& Groner, B. (1988) Prolactin regulation of betacasein gene expression and of a cytosolic $120 \mathrm{kd}$ protein in a cloned mouse mammary epithelial cell line. $E M B O$. Jl 7, 2089-2095.

Bisbee, C.A. \& Rosen, J.M. (1986) DNA sequence elements regulating casein gene expression. In Transcription Control Mechanisms, pp.313-323. Eds D. Granner, M. G. Rosenfeld \& S. Chang. Alan R. Liss, New York.

Bouchard, L., Lamarre, L., Tremblay, P.J. \& Jolicoeur, P. (1989) Stochastic appearance of mammary tumors in transgenic mice carrying the MMTV/c-neu oncogene. Cell 57, 931-936.

Brinster, R.L., Allen, J.M., Behringer, R.R., Gelinas, R.E. \& Palmiter, R.D. (1988) Introns increase transcriptional efficiency in transgenic mice. Proc. natn. Acad. Sci. USA 85, 836-840.

Campbell, S.M., Rosen, J.M., Hennighausen, L., Strech-Jurk, U. \& Sippel, A.E. (1984) Comparison of the whey acidic protein genes of the rat and mouse. Nucleic Acids Res. 12, 8685-8697.

Choi, Y.W., Henard, D., Lee, I. \& Ross, S.R. (1987) The mouse mammary tumor virus long terminal repeat directs expression in epithelial and lymphoid cells of different tissues in transgenic mice. J. Virol. 61, 3013-3019.

Clark, A.J., Simons, J.P., Wilmut, I. \& Lathe, R. (1987) Pharmaceuticals from transgenic livestock. Tibtech. 5, 20-24.

Clark, A.J., Bessos, H., Bishop, J.O., Brown, P., Harris, S., Lathe, R., McClenaghan, M., Prowse, C., Simons,
J.P., Whitelaw, C.B.A. \& Wilmut, I. (1989) Expression of human anti-hemophilic factor IX in the milk of transgenic sheep. Bio/Technology 7, 487-492.

David-Inouye, Y., Couch, C.H. \& Rosen, J.M. (1986) The isolation and transfection of the entire rat $\beta$-casein gene. Ann. N.Y. Acad. Sci. 478, 274-277.

Devinoy, E., Hubert, C., Jolivet, G., Thepot, D., Clergue, N., Desaleux, M., Dion, M., Servely, J.-L. \& Houdebine, L.-M. (1988) Recent data on the structure of rabbit milk protein genes and on the mechanism of the hormonal control of their expression. Reprod. Nutr. Develop. 28, 1145-1164.

Doppler, W., Groner, B. \& Ball, R.K. (1989) Prolactin and glucocorticoid hormones synergistically induce expression of transfected rat $\beta$-casein gene promotor constructs in a mammary epithelial cell line. Proc. natn. Acad. Sci. USA 86, 104-108.

Fox, P.F. (Ed.) (1982) Developments in Dairy Chemistry1. Applied Science Publishers Ltd, London.

Gaye, P., Hue-Delahaie, D., Mercier, J.-C., Soulier, S., Vilotte, J.-L. \& Furet, J.-P. (1986) Ovine B-lactoglobulin messenger RNA: nucleotide sequence and mRNA levels during functional differentiation of the mammary gland. Biochemie 68, 1097-1107.

Gordon, K., Lee, E., Vitale, J.A., Smith, A.E., Westphal, H. \& Hennighausen, L. (1987) Production of human tissue plasminogen activator in transgenic mouse milk. Bio/Technology 5, 1183-1187.

Gorodetsky, S.I., Tkach, T.M. \& Kapelinskaya, T.V. (1988) Isolation and characterisation of the Bos taurus $\beta$-casein gene. Gene 66, 87-96.

Hall, L., Emery, D.C., Davies, M.S., Parker, D. \& Craig, R.K. (1987) Organisation and sequence of the human $\alpha$-lactalbumin gene. Biochem. J. 242, 735-742.

Harris, S., Ali, S., Anderson, S., Archibald, A.L. \& Clark, A.J. (1988) Complete nucleotide sequence of the genomic ovine $\beta$-lactoglobulin gene. Nucleic Acids Res. 16, 10379-10380.

,Hennighausen, L.G. \& Sippel, A.E. (1982) Mouse whey acidic protein is a novel member of the family of 'four-disulphide core' proteins. Nucleic Acids Res. 10, 2677-2684.

Jenness, R. (1982) Interspecies comparison of milk proteins. In Developments in Dairy Chemistry-1. pp. 87-114. Ed. P. F. Fox. Applied Sciences Publishers Ltd, London.

Jimenez-Flores, R. \& Richardson, T. (1988) Genetic engineering of the caseins to modify the behaviour of milk during processing: a review. J. Dairy Sci. 71, 2640-2654. 
Jones, W.K., Yu-Lee, Y.-L., Clift, S.M., Brown, T.L. \& Rosen, J.M. (1985) The rat casein multigene family: fine structure and evolution of the $\beta$-casein gene, $J$. biol. Chem. 260, 7042-7050.

Kawara, K., Satow, H., Dolk, L., Sakai, S., Takada, S. \& Obinata, M. (1987) Modulation of the transferred mouse $26 \mathrm{~K}$ casein gene in mouse L cells by glucocorticoid hormone. J. Biochem. 101, 103-110.

Laird, J.E., Jack, L., Hall, L., Boulton, A.P., Parker, D. \& Craig, R.K. (1988) Structure and expression of the guinea pig $\alpha$-lactalbumin gene. Biochem. J. 254, $85-94$.

Lathe, R., Clark, A.J., Archibald, A.L., Bishop, J.O., Simons, J.P. \& Wilmut, I. (1986) Novel products from livestock. In Exploiting New Technologies in Animal Breeding: Genetic Developments, pp. 91-102. Eds C. Smith, J. W. B. King \& J. C. McKay. Oxford University Press, Oxford.

Leder, A., Pattengale, P.K., Kuo, A., Stewart, T.A. \& Leder, P. (1986) Consequences of widespread deregulation of the c-myc gene in transgenic mice: multiple neoplasms and normal development. Cell 45, 485-495.

Lee, K.-F., DeMayo, F.J., Atiee, S.H. \& Rosen, J.M. (1988) Tissue-specific expression of the rat betacasein gene in transgenic mice. Nucleic Acids Res. 16, 1027-1041.

Lee, K.-F., Atiee, S.H. \& Rosen, J.M. (1989) Differential regulation of rat $\beta$-casein-chloramphenicol acetyltransferase fusion gene expression in transgenic mice. Molec, cell. Biol. 9, 560-565.

Levine, J.F.\& Stockdale, F.E. (1985) Cell-cell interactions promote mammary epithelial cell differentiation. $J$. Cell. Biol. 100, 1415-1422.

Li, M.L., Aggeler, J., Farson, D.A., Hatier, C., Hassell, J. \& Bissel, M.J. (1987) Influence of a reconstituted basement membrane and its components on casein expression and secretion in mouse mammary epithelial cells. Proc. natn. Acad. Sci. USA 84, 136-140.

Lubon, H. \& Hennighausen, L. (1987) Nuclear proteins from lactating glands bind to the promoter of a milk protein gene. Nucleic Acids Res. 15, 2103-2121.

Lubon, H. \& Hennighausen, L. (1988) Conserved region of the rat $\alpha$-lactalbumin promoter is a target site for protein binding in vitro. Biochem. J. 256, 39 I-396.

Mehta, N.M., El-Gewely, R.M., Joshi, J., Helling, R.B. \& Benerjee, M.H. (1981) Cloning mouse $\beta$-casein gene sequences. Gene 15, 285-288.

Muller, W.J., Sinn, E., Pattengale, P.K., Wallace, R. \& Leder, P. (1988) Single-step induction of mammary adenocarcinoma in transgenic mice bearing the activated c-neu oncogene. Cell 54, 105-115.

Palmiter, R.D. \& Brinster, R.L. (1986) Germline transformation of mice. Ann. Rev. Genet. 20, 465-499.

Pervaiz, S. \& Brew, K. (1985) Homology of $\beta$-lactoglobulin, serum albumin and its similarity to plasma retinol-binding protein. Nature, Lond. 324, 383-385.

Qasba, P.K. \& Safaya, S.K. (1984) Similarity of the nucleotide sequences of rat $\alpha$-lactalbumin and chicken lysozyme genes. Nature, Lond. 308, 377-380.

Rosen, J.M., Rodgers, J.R., Couch, C.H., Bisbee, C.A., David-Inouye, Y., Campbell, S.M. \& Yu-lee, K.-Y. (1986) Multihormonal regulation of milk protein gene expression. Ann. N.Y. Acad. Sci. 478, 63-76.
Ross, S.R. \& Solter, D. (1985) Glucocorticoid regulation of mouse mammary tumor virus sequences in transgenic mice. Proc. natn. Acad. Sci. USA 82, 5880-5884.

Scangos, G. \& Bieberich, C. (1987) Gene transfer into mice. Adv. Genet. 24, 285-323.

Schonenberger, C.-A. Andres, A.-C., Groner, B., Van der Valk, M., LeMeur, M. \& Gerlinger, P. (1988) Targeted c-myc gene expression in mammary glands of transgenic mice induces mammary tumours with constitutive milk protein gene transcription. $E M B O$ $J l 7,169-175$.

Simons, J.P. \& Land, R.B. (1987) Transgenic livestock. $J$. Reprod. Fert., Suppl. 34, 237-250.

Simons, J.P., McClenaghan, M. \& Clark, A.J. (1987) Alteration of the quality of milk by expression of sheep $\beta$-lactoglobulin in transgenic mice. Nature, Lond. 328, $530-532$.

Simons, J.P., Wilmut, I., Clark, A.J., Archibald, A.L., Bishop, J.O. \& Lathe, R. (1988) Gene transfer into sheep. Bio/Technology 6, 179-183.

Sollner-Webb, B. \& Reeder, R.H. (1979) The nucleotide sequences of the initiation and termination sites for ribosmal RNA transcription in $X$. laevis. Cell 18, 485-499.

Stewart, T.A., Pattengale, P.K. \& Leder, P. (1984) Spontaneous mammary adenocarcinomas in transgenic mice that carry and express $\mathrm{MTV} /$ myc fusion genes. Cell 38, 627-637.

Topper, Y.J. \& Freeman, C.S. (1980) Multiple hormone interactions in the developmental biology of the mammary gland. Physiol. Reviews 60, 1049-1106.

Topper, Y.J., Oka, T. \& Vonderhaar, B.K. (1975) Techniques for studying development of normal mammary epithelial cells in organ culture. Meths Enzymol. 39, 443-454.

Tremblay, P.J., Pothier, F., Hoang, T., Tremblay, G., Brownstein, S., Liszauer, A. \& Jolicoeur, P. (1989) Transgenic mice carrying the mouse mammary tumor virus ras fusion gene: distinct effects in various tissues. Molec. cell. Biol. 9, 854-859.

Tsukamoto, A.S., Grosschedl, R., Guzman, R.C., Parslow, T. \& Varmus, H.E. (1988) Expression of the int-1 gene in transgenic mice is associated with mammary gland hyperplasia and adenocarcinomas in male and female mice. Cell 55, 619-625.

Vilotte, J.-L., Soulier, S., Mercier, J.-C., Gaye, P., Hue-Delahaie, D. \& Furet, J.-P. (1987) Complete nucleotide sequence of bovine $\alpha$-lactalbumin gene. Comparison with its rat counterpart. Biochemie 69 , 609620 .

Wagner, T.E. \& Murray, F.A. (1985) Genetic engineering of laboratory and livestock mammals. J. Anim. Sci. 61, 25-37.

Yu-Lee, L.-Y. \& Rosen, J.M. (1983) The rat casein multigene family. Fine structure of the gamma-casein gene. J. biol. Chem. 258, 10794-10804.

Yu-Lee, Y.-Y., Richter-Mann, L., Couch, C.H., Stewart, A.F., Mackinley, A.G. \& Rosen, J.M. (1986) Evolution of the casein multigene family: conserved sequences in the $5^{\prime}$ flanking and exon regions. Nucleic Acids. Res. 14, 1883-1902. 